\title{
Methylcytosine Dioxygenase TET1
}

National Cancer Institute

\section{Source}

National Cancer Institute. Methylcytosine Dioxygenase TET1. NCI Thesaurus. Code C95425.

Methylcytosine dioxygenase TET1 (2136 aa, $235 \mathrm{kDa}$ ) is encoded by the human TET1 gene. This protein is involved in the mediation of DNA methylation. 